\title{
BAKING QUALITY OF WINTER WHEAT (TRITICUM AESTIVUM L.) IN THE LONG-TERM EXPERIMENTS ON CHERNOZEM SOIL
}

\author{
Peter Pepó \\ University of Debrecen, H-4032 Debrecen Böszörményi str. 138., e-mail: pepopeter@agr.unideb.hu, telephone: 52/508-463; fax: 52/508-462
}

Keywords: baking quality, winter wheat, long-term experiment

\section{SUMMARY}

\begin{abstract}
Agriculture has traditionally an important role in Hungarian economy and rural development. About $75 \%$ of Hungary's total territory is under agricultural land use. Because of ecological conditions and production traditions cereals (wheat, maize etc) have the greatest importance in Hungarian crop production. In the 1980's the country-average yields of wheat were about 5,0-5,5 tha-1 (,industrial-like" crop production-model). In the 1990's the yields of wheat dropped to 4,0 tha-l because of low input-using and wide application of the issues of environmental protection and sustainability. Winter wheat production for quality has a decisive role in certain regions of Hungary (eastern and middle-parts).

The quality of wheat is complex and different. Three major growing factor groups determine the quality of winter wheat: genotype, agroecological conditions and agrotechnical factors. In wheat production for quality the selection of the variety is the most important element. Our long-term experiments proved that the quality traits of a variety means the highest (maximum) limit of quality which could not be exceeded in fact. During the vegetation period of wheat the different ecological and agrotechnical factors could help or on the contrary could demage the quality parameters of wheat.

The agrotechnical factors determining the baking quality of wheat can be divided into two groups: the first group means the factors with direct effects on quality (fertilization, irrigation, harvest); the second group contains the elements with indirect effects on quality (crop rotation, tillage, planting, crop protection).

Appropriate fertilization could help to manifest the maximum of quality parameters of a wheat genotype and could reduce the qualityfluctuation in unfavourable ecological and agrotechnical conditions.
\end{abstract}

\section{INTRODUCTION}

The winter wheat is one of mankind's ancient grains and in Hungary's plant cultivation is one of the most important crops (Barnard and Bona 2004).

The quality of wheat is determined by a complex of factors including biological bases (variety, seed), agroecological conditions (weather, soil) and the growing management practices applied (Erdei and Szániel 1975, Bocz et al. 1983, Pepó 1991, Matuz et al. 1999, Pepó 2000, Pepó 2001, Kertész és Matuz 2001).

Winter wheat is produced almost on every farm or estate. It is vital to focus on the quality of the crop not only on its quantity. The quality of winter wheat is determined by the biological basis, the agro-ecological circumstances and the agrotechnology altogether (Bocz et al. 1983, Pepó 2000). In the last decade the level of agronomical expenditures decreased. Plant improvement tried to adjust itself to the reduced input application and resulted in the appearance of more and more, stronger varieties with better adaptability (Pepó, 2002). Hungary's agro-ecological characteristics provide adequate ground for the qualitative wheat production (Szabó et al., 1987). From the agrotechnical factors, the nutrient supply has a significant effect on the quality and quantity of wheat (Ragasits, 1998). A fertilizer in the adequate dose, rate and splitting can ensure the quality parameters and moderate the negative effects of the unfavorable ecological and agro-technical factors (Györi et al. 1998, Jolánkai et al. 1998).

\section{MATERIALS AND METHODS}

Our different normal and long-term experiments were carried out in Hajdúság on chernozem soil (small-plots experiments) and in eastern parts of Hungary on chernozem, meadow and brown forest soils (big-plots experiments). In our small-plot experiments different small grain cereals (mainly winter wheat and winter barley, spring barley, triticale) and other cereal (maize) were studied. The most important crop production factors which were studied in our normal and long-term experiments were the followings:

- agrometeorological factors (rainfall, temperature, insolation etc) - cropyear effect on the yield, yield stability, yield-quality and soil water- and nutrient-husbandry (environmental protection aspects)

- biological-genetic background of wheat production (variety/hybrid testing and responses of different varieties/hybrids to different agrotechnical elements)

- individual and interactive effects of different agrotechnical elements on the yield-performance and quality of wheat (including crop rotation, fertilization, planting-technology, crop protection, harvest).

In different small and big plots experimental projects yields, different phenological, phenometrical, agronomical traits, quality-parameters, soil physical, chemical and biological characters etc were measured.

Our long-term experiments were carried out in eastern part of Hungary on calcareous chernozem soil. It has average $\mathrm{N}$ and $\mathrm{P}$ content and high $\mathrm{K}$ content (humus content $=2,8-3,0 \%$, total $\mathrm{N}=0,14-0,18 \%, \mathrm{AL}_{2} \mathrm{P}_{2} \mathrm{O}_{5}=130$ $200 \mathrm{mg} \mathrm{kg}^{-1}, \mathrm{AL}-\mathrm{K}_{2} \mathrm{O}=240-280 \mathrm{mg} \mathrm{kg}^{-1}$ ). The depth of humus layer is $70-90 \mathrm{~cm}$. The $\mathrm{pH}$ value is 6,2 , the "Arany-type" physical texture is 43 . The ground water level is under $3 \mathrm{~m}$. The minimum water holding capacity 
(WHCmin) of the soil is $27-29$ volume \%. The water storage capacity of the soil is $275 \mathrm{~mm}$ in the $0-100 \mathrm{~cm}$ profile and $265 \mathrm{~mm}$ in the $100-200 \mathrm{~cm}$ profile. The disponible WHC is $157 \mathrm{~mm}$ and $150 \mathrm{~mm}$ in the $0-100 \mathrm{~cm}$ and $100-200 \mathrm{~cm}$ profile, respectively.

Flour was prepared by a laboratory mill (Labor-Mim QC-109, Budapest, Hungary) from winter wheat using 250 $\mu \mathrm{m}$ bolting cloths. The wet gluten content was determined in accordance with Hungarian Standard MSZ ISO 5531 by using Glutomatic Perten equipment (Hamburg, Germany) while the farinograph values were obtained in accordance with Hungarian Standard MSZ ISO 5530-3 with Brabender Farinograf FQA equipment and also by using Brabender Farinograph SEW (Duisburg, Germany).

\section{RESULTS AND DISCUSSION}

By making use of the quality testing data of the long term experiment, the effects of fertilizer application on wet gluten content and farinograph value were determined for each production year and the average of production years as well. During the eighteen years of the long term experiment (in 1986 the gluten content was not tested) fertilizer application increased the gluten content of wheat considerably in general, and markedly if the averages of certain production years are taken. The $27.60 \%$ gluten content obtained in the control treatment increased by $4 \%$ in absolute terms $(31.62 \%)$ when the smallest ratio $\left(\mathrm{N}_{60 / 30}+\mathrm{PK}\right)$ was applied and this increase although at a decreasing rate - continued consequently up to the application of the highest ratio $\left(\mathrm{N}_{300 / 150}+\mathrm{PK}\right)$, which treatment yielded the maximum gluten content $(35,97 \%)$. In both fertilization periods (1985-1996. years $\mathrm{R}^{2}=0,9679,1997-2003$. years $\mathrm{R}^{2}=0,9806$ ) the parabolic curves, obtained by using regression analysis (Figure 1 ) fit the average data of many years extremely well.

Figure 1.: Determination of the relationship between fertilizer application and gluten content with regression analysis (Debrecen, mean values of varieties)
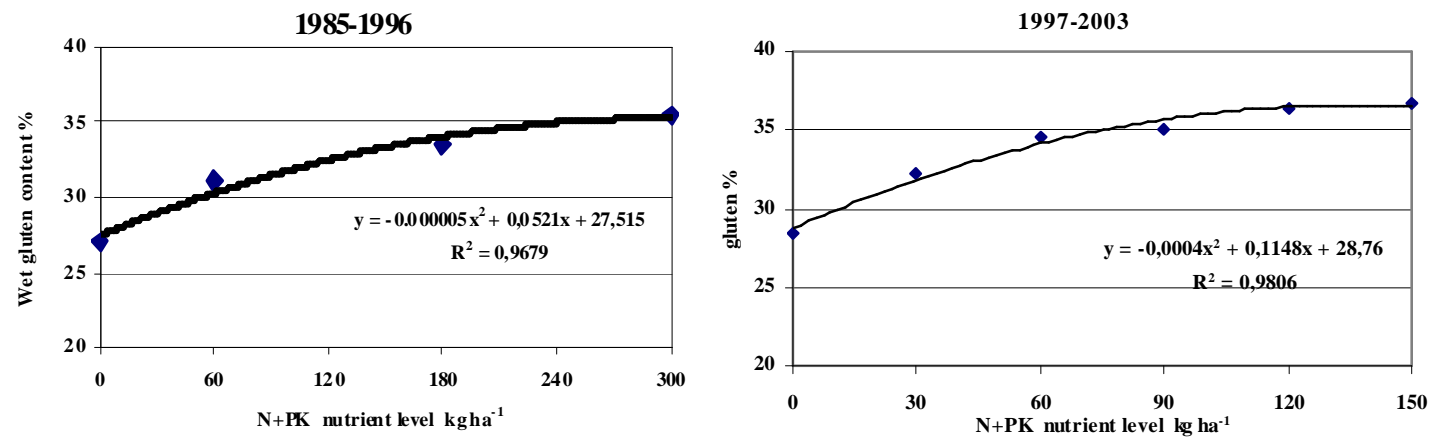

Both as regards each production year and the mean values of the years, fertilizer application also positively influenced the farinograph values of the wheat varieties, analysed but the effect of fertilizers was far from being so crucial in the case of wet gluten contents. This refers to the fact that while gluten content (primarily the amount of protein) can clearly and relatively "easily" be increased by applying higher nitrogen fertilizer (and phosphorous and potassium) doses, in the case of farinograph values, in which the ratios of structural and stuffing proteins as well as ones with small and large molecule weights are crucial, other factors (e.g. the weather) also play a vital role. Accordingly, the 56.2 farinograph value for the control treatment increased moderately (58.6) in the $\mathrm{N}_{60 / 30}+\mathrm{PK}$ treatment and showed further moderate increases (61.4) up to the treatment with the highest fertilizer dose $\left(\mathrm{N}_{300 / 150}+\mathrm{PK}\right)$. This means that although the baking quality did improve but the quality of both the control and the treated yields were classified as medium baking quality $\left(\mathrm{B}_{1}\right)$ in the average of a number of years (Figure 2).

Figure 2.: Determination of the correlation between fertilizer application and farinograph readings with regression analysis (Debrecen, mean values of the varieties)
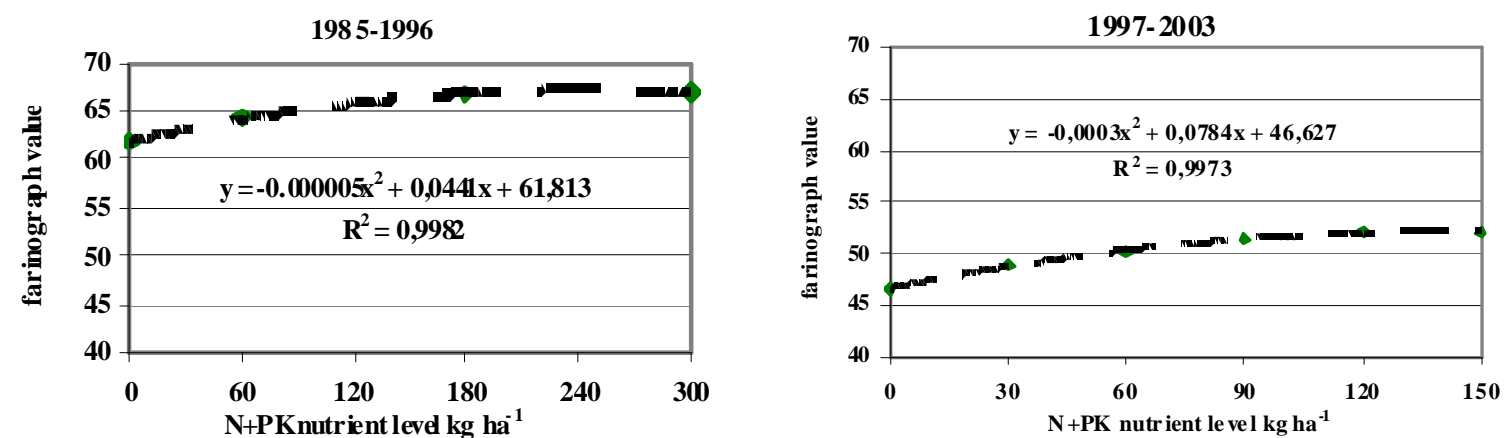
Appropriate fertilizer application may not only increase the gluten content (considerably) and the farinograph values (moderately) but the stability of the quality of different wheat genotypes may also be made more stable. Our experimental findings demonstrate that when fertilizer treatments are applied fluctuations in both gluten contents and farinograph values showed considerable decreases in relation to the control. In other words, fertilizer application did not only bring about quality improvements but resulted in a more favourable stability of quality as well. The evaluation of the data for the whole of the testing period revealed that either gluten contents or farinograph value showed the least changes at a fertilizer dose of $\mathrm{N}_{240 / 120}+\mathrm{PK}(27.5 \%$, and $57.3 \%$ fluctuation as opposed to those of $49,1 \%$, and $95,3 \%$ in the control).

The relationship between the weather factors and the quality of winter wheat was over the period 1986-2003 was evaluated by using the principal component analysis. The findings of the major component analyses for gluten contents and valorigraph readings are contained in Tables 1 and 2, respectively.

Gluten contents were determined up to $65.7 \%$ by the meteorological factors involved in the scope of the study (cumulative own value), which means that with the three background variables the total variance of the system can be interpreted up to two thirds of the total. Factor number I. can be regarded to be the dominant background variable (26.7\% total variance), in the case of which a close correspondence can be established between primarily the mean temperature in July (kernel filling processes) and partly that in May (the formation of the vegetative sink, which later ensures the translocation of nutrients into the grain crop) as well as the gluten contents of the different varieties. The effects of factors II and III are more moderate (total variances of $22.8 \%$; and $16.2 \%)$. In the case of factor II the more moderate effect on the gluten content is exercised by the precipitation in May and the temperature in July (Table 1).

Table 1.

Evaluation of the effect of meteorological parameters on the wet gluten content of winter wheat varieties by principal component analyses (Debrecen, 1986-2003, all varieties)

\begin{tabular}{|l|c|c|c|}
\hline \multirow{2}{*}{\multicolumn{1}{|c|}{ Factors }} & \multicolumn{3}{c|}{ Components } \\
\cline { 2 - 4 } & I & II & III \\
\hline Temperature in June & 0,921 & 0,145 & $-0,116$ \\
Temperature in May & 0,698 & $-0,605$ & $-2,290 \mathrm{E}-02$ \\
Wet gluten & 0,418 & 0,299 & $5,924 \mathrm{E}-02$ \\
Precipitation in May & $-0,175$ & 0,834 & $-0,334$ \\
Temperature in July & 0,313 & 0,575 & 0,229 \\
Precipitation in June & $-0,278$ & $-3,187 \mathrm{E}-02$ & 0,832 \\
Precipitation in July & 0,388 & 0,311 & 0,511 \\
\hline Total of Initial Eigenvalues & 1,866 & 1,599 & 1,136 \\
Variance \% & 26,655 & 22,849 & 16,225 \\
Cumulative \% & 26,655 & 49,503 & 65,728 \\
\hline
\end{tabular}

In contrast with the gluten content the valorigraph value is a baking industry parameter that is not only a quantitative but primarily a qualitative one, which expresses the compositions and proportions of the different gluten proteins formed (structural and frame composing filling, small- and large-molecule-weight proteins, etc). As a consequence, the effects of weather factors influencing valorigraph values, to some extent deviated from the finding for gluten contents. The results of the analysis for the principal component conducted for all the varieties reveal that the three background components may be applied to interpret up to $64.8 \%$ of the total variance of the system. Factor I can be considered as the dominant background variable ( $29.3 \%$ total variance), while the effects of the other two factors are more moderate. At the same time as our investigations revealed the effects of the mean temperatures in May and June had the most significant effects on valorigraph values but these influenced them in a negative way (Table 2).

Table 2.

Evaluation of the effect of meterological parameters on the valorigraph index of winter wheat varietes by principal component analyses (Debrecen, 1986-2003, all varieties)

\begin{tabular}{|l|c|c|c|}
\hline \multirow{2}{*}{\multicolumn{1}{|c|}{ Factors }} & \multicolumn{3}{c|}{ Components } \\
\cline { 2 - 4 } & I & II & III \\
\hline Temperature in May & 0,869 & $-0,235$ & $-0,130$ \\
Temperature in June & 0,741 & 0,567 & $-0,167$ \\
Valorigraph value & $-0,683$ & 0,132 & $-0,262$ \\
Temperature in July & 0,116 & 0,668 & 0,372 \\
Precipitation in May & $-0,481$ & 0,637 & $-9,224 \mathrm{E}-02$ \\
Precipitation in July & 0,160 & 0,509 & 0,289 \\
Precipitation in June & $-8,382 \mathrm{E}-02$ & $-0,263$ & 0,906 \\
\hline Total of initial Eigenvalues & 2,049 & 1,575 & 1,165 \\
Variance \% & 29,278 & 22,498 & 16,643 \\
Cumulative \% & 29,278 & 51,776 & 68,419 \\
\hline
\end{tabular}


In the case of the varieties studied it was the valorigraph value deteriorating effect of the precipitation in July indicated in factor III. that prevailed.

Our analysis data also proved that the correlations manifest themselves in the different varieties in different ways. Under the effect of fertilization, both the gluten contents and farinograph values of the varieties changed and increased in different ways in relation to the control. In order to prove this claim we are showing the gluten contents (Figure 3) and farinograph values (Figure 4) of different genotypes receiving increasing fertilizer doses in two very different production years (2002 and 2003). In both varieties the changes in the two parameters greatly depended on the weather conditions of the production year. It can, however, be seen that there were varieties in which gluten contents increased moderately (e.g. Mv Csárdás), showed average increases (e.g. Mv Verbunkos) or the increases were significant (e.g.. GK Öthalom). Despite the changes and increases the differences between the varieties remained in both the control and the fertilizer treatments $\left(\mathrm{N}_{30}-\mathrm{N}_{150}+\mathrm{PK}\right)$ with increasing ratios (in variety Mv Csárdás), which responded with a moderate increase, the control treatment in 2002 and 2003 showed $31.80 \%$ and $37.25 \%$, respectively, while the same values for the fertilizer $\mathrm{N}_{150}+\mathrm{PK}$ treatments in the same years were $40.96 \%$, and $39.04 \%$. In the case of GK Öthalom they were $23.22 \%$, and $21.91 \%$ in the control treatment and $32.13 \%$, and $38.51 \%$ in the $\mathrm{N}_{150}+\mathrm{PK}$ fertilizer treatment). Changes, similar to those experienced in the case of gluten were experienced with farinograph values as well, though these were more moderate and variety-specific. In certain varieties the farinograph values changed more considerably in response to fertilizer application.

Figure 3.: Variety specific effects of fertilizer application on the wet gluten content of winter wheat varieties (Debrecen, 2002-2003)
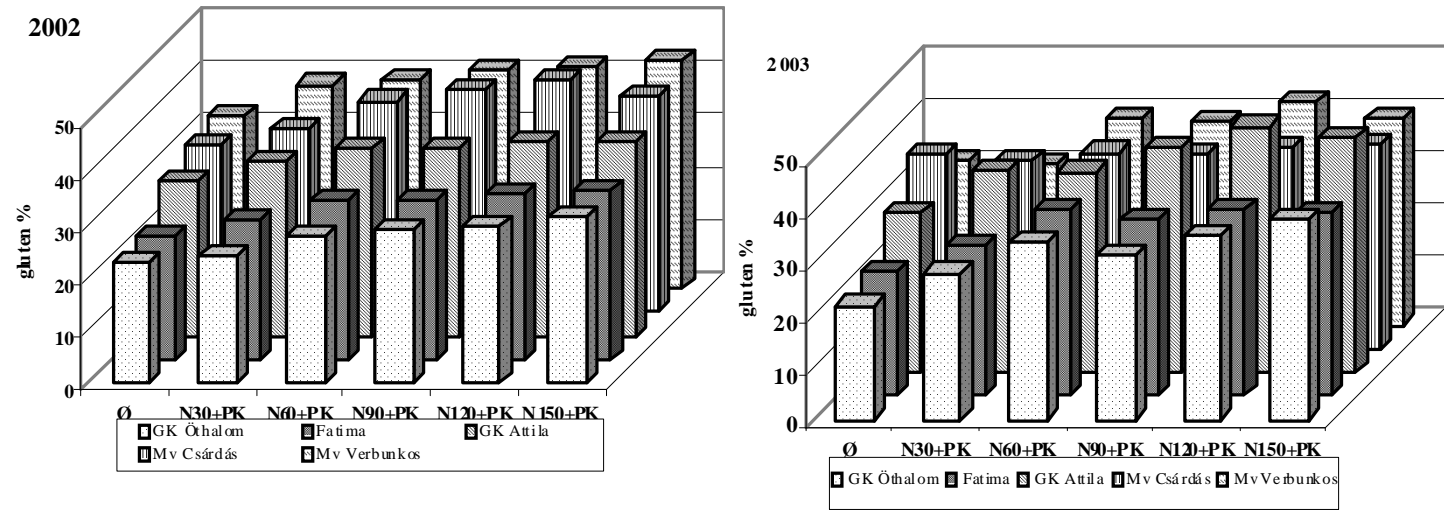

Figure 4.: Variety specific effects of fertilizer application on the farinograph values of winter wheat varieties (Debrecen, 2002-2003)
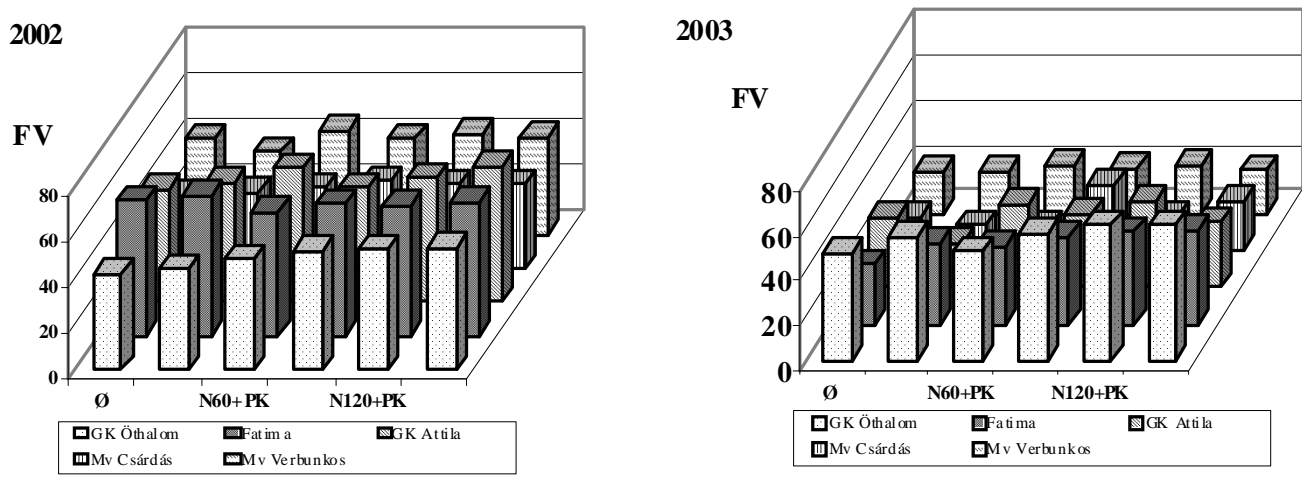

\section{CONCLUSIONS}

According to our findings the different cropping years influenced the quality of winter wheat to smaller or larger extents. The effects of the cropping year on gluten contents were much smaller than on valorigraph values. Adequate nutrient supplies $\left(\mathrm{N}_{300 / 150}+\mathrm{PK}\right.$ treatment, $31-43 \%$ gluten on the average of the varieties in the different years) ensured high and stable gluten contents, while valorigraph values were much more significantly influenced by the effects of the cropping years even at very favourable fertilizer treatments (at $\mathrm{N}_{300 / 150}+\mathrm{PK}$ treatment it ranged between values $\left.39\left[\mathrm{C}_{1}\right]-80\left[\mathrm{~A}_{2}\right]\right)$.

The medium strong correlation between the gluten content and the farinograph reading were considerably diverted, modified in the different years. Especially in dry, arid years it was experienced that despite high gluten contents (36-43\%) but supposedly due to the inadequate formation of the gluten structure valorigraph values revealed unfavourable (39-59) trends. According to the principal component analysis the gluten contents were 
determined by the temperatures in May-July and were modified by the precipitation in May and the temperatures in June in relation to all the varieties. The combined quality indicator, i.e. the valorigraph value reacted to the weather conditions in somewhat different ways than gluten contents did. As regards all the varieties the principal component analysis showed that it was the temperatures in May and July that had the most significant effects on the valorigraph values. High temperatures in these months deteriorated the valorigraph values of the different varieties.

Usage of appropriate agrotechnical methods and elements could effectively reduce the harmful or negative effects of cropyears on quantity and baking quality of yields in winter wheat production, but we can not eliminate the all negative effects. Our long-term experimental results proved that the changes of baking quality parameters were variety specific.

\section{REFERENCES}

Barnard, A. \& Bona, L. (2004): Sprout damage and falling number in South African and Hungarian wheats. Cereal Research Communications. 32. 2. 259-264.

Bocz, E., Pepó, Pé., Pepó Pá. (1983): A víz- és tápanyag szerepe a termésminőségben. Őszi búza. Magyar Mezőgazdaság, 38.41 .8$.

Erdei P. \& Szániel, I. (1975): A minőségi búza termesztése. Mezőgazdasági Könyvkiadó. Budapest. 128.

Győri Z., \& Győriné Mile, I. (1998): A búza minősége és minősítése. Mezőgazdasági Szaktudás Kiadó, Budapest. 46-57.

Jolánkai, M., Szentpétery, Zs., Szalai, T. (1998): A búza minőségének alakulása agrokémiai kezelésekben, kedvező és kedvezőtlen évjáratokban. Gyakorlati Agrofórum. 9. 10, 22-24.

Kertész, Z.-Matuz, J. (2001): Nagy sikértartalmú szegedi fajták. Magyar Mezőgazdaság. 56. 42. 10-11.

Matuz, J., Markovics, E., Ács, E., Véha, A. (1999): Öszi búzafajták lisztjének minőségi tulajdonságai közötti összefüggések vizsgálata. Növénytermelés, 48. 3. 243-253.

Pepó, Pé. (1991): Öszi búzafajták trágyázása és öntözése. Kandidátusi értekezés. Debrecen.

Pepó, Pé. (2000): A minőségi búzatermesztés genetikai alapjai. VI. Növénynemesítési Tudományos Napok. 27.

Pepó, Pé. (2001): Wheat production for quality in Hungary. CIEC 12 ${ }^{\text {th }}$ World Fertilizer Congress. Beijing, China. 263.

Pepó, Pé. (2002): Őszibúza-fajták trágyareakciója eltérő évjáratokban. Növénytermelés. 51. 2, 189-197.

Ragasits, I. (1998): A búza terméselemeinek változása a műtrágyázás hatására. Gyakorlati Agrofórum. 9. 10, 29 -31.

Szabó, M., Ángyán, J., Forgács, M., Tirczka, I. (1987): Magyarország klimatikus adottságainak biometriai elemzése az őszi búza termésátlaga és minősége szempontjából. Növénytermelés. 36. 